Research Article

Uranchimeg Tudevdagva*, Ariane Heller, and Wolfram Hardt

\title{
Case Study Experiences on Active Learning Methods in Germany
}

https://doi.org/10.1515/edu-2020-0154

Received Apr 13, 2021; accepted Jul 2, 2021

Abstract: This article describes the implementation of active learning methods in engineering courses. The implementation was part of the activities of the international Erasmus project DriveMATH, which ran between 2017 and 2020. The active learning methods eduScrum, JigSaw, problem based learning, practical and team-based learning were used for courses for the master's degree at Chemnitz University of Technology. Research seminar computer science, research internship and internship automotive software engineering were selected as courses for implementation. The students were invited to participate in the implementation on a voluntary basis. At the end of the implementation, the project team asked the students for feedback in the form of an evaluation survey. Criteria for the evaluation were developed in the team of the partner universities of the project. The data obtained were evaluated with the help of the structure-oriented evaluation model (SURE model).

Keywords: eduScrum, JigSaw, ASE, active learning, evaluation, SURE model

\section{Course descriptions}

Active learning methods have been implemented in the following courses: 500090 - "Research Seminar for Computer Science”, 500170 - "Research Internship” and 555170 - "Practical Training Automotive Software Engineering”.

\footnotetext{
${ }^{\star}$ Corresponding Author: Uranchimeg Tudevdagva: Technische Universität Chemnitz, Germany; E-mail: uranchimeg.tudevdagva@informatik.tu-chemnitz.de Ariane Heller: Technische Universität Chemnitz, Germany; E-mail: ariane.heller@informatik.tu-chemnitz.de Wolfram Hardt: Technische Universität Chemnitz, Germany; E-mail: wolfram.hardt@informatik.tu-chemnitz.de
}

\subsection{Research Seminar Computer Science}

Short description of course:

- Offering faculty: Faculty of Computer Science, Computer Engineering Professorship

- Availability: Each semester

- Workload: 150 working hours

Content of course: The seminar topic relates to the pillars of the study course. The students work on the topic on their own, present it for discussion and write a paper, which meets the requirements of a scientific thesis.

Qualification aim: The students are introduced to independent work on research-relevant problems.

The "Research Seminar for Computer Science" (in German: Hauptseminar AUTOSAR Based Software Design) was selected as course for implementation of the eduScrum method. The eduScrum method was applied during the winter semester 2018/19 and the summer semester 2019. In the first round 30 of 80 students registered to the eduScrum class, and during the second round 40 of 85 students selected the eduScrum test class.

The course is usually taught in a flipped class format. That was a challenging condition for the implementation of eduScrum. Due to this the traditional way of implementing the eduScrum method needs to be modified and adapted to the given situation. Therefore, e-learning materials were developed and placed into the university Learning Management Systems OPAL. OPAL is an online-based platform for academic teaching and learning at universities of Saxony.

The course is one of mandatory courses for Automotive Software Engineering (ASE) program. A seminar for learning scientific working methods is provided as a testbed for ARS acceptance evaluation as blended mentoring tool. The course is divided into a lecture part to impart the theoretical background and a practical exercise part. The lectures are used to explain the methods necessary for fulfilling the high scientific standards in the field of literature survey, presentation style and preparation, professional discussion as well as scientific writing and reporting. The examination is done by presenting the state of the art of a self-chosen topic and writing a scientific report of 10 to 15 pages of content. The learning outcomes of the course cover a wide range of

Ә Open Access. () 2021 Tudevdagva et al., published by De Gruyter. (Cc) BY 4.0 Public License

This work is licensed under the Creative Commons Attribution 
competences required in the field of computer engineering following the competency model of information technology (IT) industry.

The course trains competencies for students in the areas - Personal Effectiveness Competencies, Academics Competencies, Workplace Competencies and IndustryWide technical Competencies, by self determined work on real world industry topics, by using scientific methods for elaborating the presentation followed by a series of questions and a report.

\subsection{Research Internship}

Short description of course 500170 "Research Internship"

- Offering faculty: Faculty of Computer Science, Computer Engineering Professorship

- Availability: Each semester

- Workload: 450 working hours

For winter semester of 2018/2019 the subject 500170 "Research Internship" was selected for a pilot implementation of a combination of Jigsaw and project-based learning. For this, the lecture presentations were modernized and new exercise sheets based on JigSaw and project-based learning were developed.

\subsection{Practical Training Automotive Software Engineering}

Short description of 555170 "Practical Training Automotive Software Engineering”

- Offering faculty: Faculty of Computer Science, Computer Engineering Professorship

- Availability: Each Semester

- Workload: 60 working hours

For summer semester 2019 the subject "Practical Training Automotive Software Engineering" was chosen. The new teaching approach was hands-on in combination with problem-solving learning.

\section{The implementation of active learning methods}

\subsection{Team based learning by eduScrum}

What is eduScrum? eduScrum is the implementation of the project managing method, Scrum, into education processes. This idea was developed by the chemistry and physics teacher Willy Wijnands who is the Founder of Dutch eduScrum Project (Lectera, 2021). Wijnands started to apply Scrum principles to his teaching in 2011. The main benefits of using Scrum principles in teaching and learning is motivation to learn to take on complex problems and find solutions together during study (eduScrum team, 2020). The students take responsibility for what they do and I give them liberty and space. The effect is that students are engaged, more productive and their results are better. It is such a wonderful to see them developing themselves! said pioneer of eduScrum Wijnands (The eduScrum Team, 2021).

EduScrum has basic terminologies and some rules for implementation. Some of the terminologies are:

- Product Owner - professor, teacher or educator who is responsible and supervises the learning subject;

- EduScrum Team - a group of students who uses the eduScrum method during the learning process;

- Scrum Master - a student in the eduScrum Team who plays the role of team leader;

- EduScrum Team Member - a student of the eduScrum Team;

- To-Do List - scheduled plan for the eduScrum Team;

- Sprint - submission deadline for short term results.

The key terminologies and necessary additional background theory about the eduScrum method should be explained during the introduction lectures to the students within the eduScrum class.

The main rule of eduScrum is that students should work as a team which is creating a product with high quality at the end. The product of the eduScrum method is the success in learning and gained knowledge after the course. In the traditional way of teaching the teacher is usually "lecturing" the students and most of the time the learning process of students is passive: listening, reading and repeating what the teacher dictates to them. In the case of eduScrum the students are organized as a team and receive learning objectives as the "goal" of the learning process. The teacher explains to the students only the main concept and basic theory of the subject, without dictating to them what should be done to solve given problems or exercises in 
class. The students need to work together to solve the tasks and problems and gain knowledge to pass successfully at the end of the subject. The Scrum Master is the main organizer of the team and helps the eduScrum Team Members to work cooperatively and actively together.

The implementation of the active learning method eduScrum is modified for the usage in a flipped class. Originally eduScrum is designed for face to face teaching. But for flipped classes face to face teaching is only one part of teaching. The duration of an academic semester at CUT is 15 weeks. During the first four weeks students attend traditional face to face classroom lectures. During the middle part of the semester the students work six weeks at home alone. In the remaining five weeks students return to the classroom to give a presentation to the peer learners. So that the eduScrum method could be used within the pre-defined course structure it was necessary to apply it to the learning management system OPAL. OPAL is used for e-learning within the universities of Saxony, Germany. The Learning Management System OPAL is based on the e-learning platform OLAT. This is an open source project of the University of Zurich. The Java-based platform was first published in 2004 under the Apache License 2.0. OPAL is used in 11 Saxon universities. The web-based application is already used by more than 60,000 university members of the Free State of Saxony.

As already mentioned, in a flipped class students have to work alone at home for some weeks . To support students with 24/7 tutoring services, an online e-learning course in OPAL was created. Figure 1 shows an example of the OPAL course especially defined for the flipped class situation (Nicola, Pinto \& Mendonça, 2018; Pinto, et al, 2019; Tudevdagva, Heller \& Hardt, 2020). All activities of the

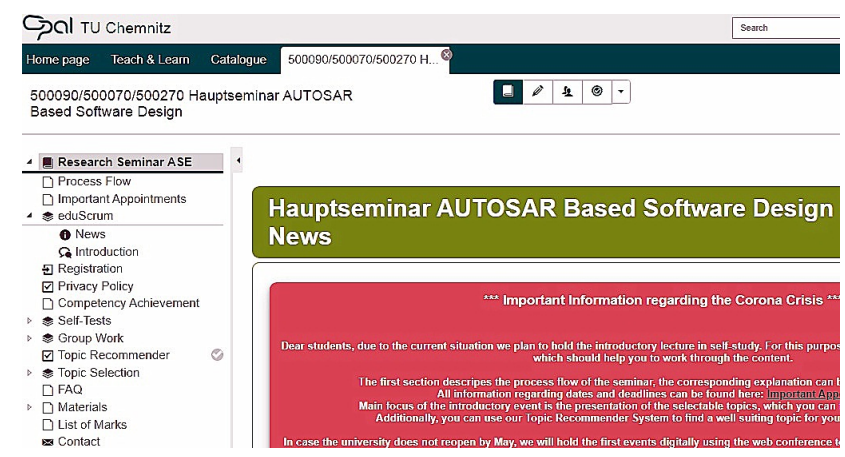

Figure 1: Main page of course in OPAL

eduScrum method are specified within the OPAL course as additional elements.

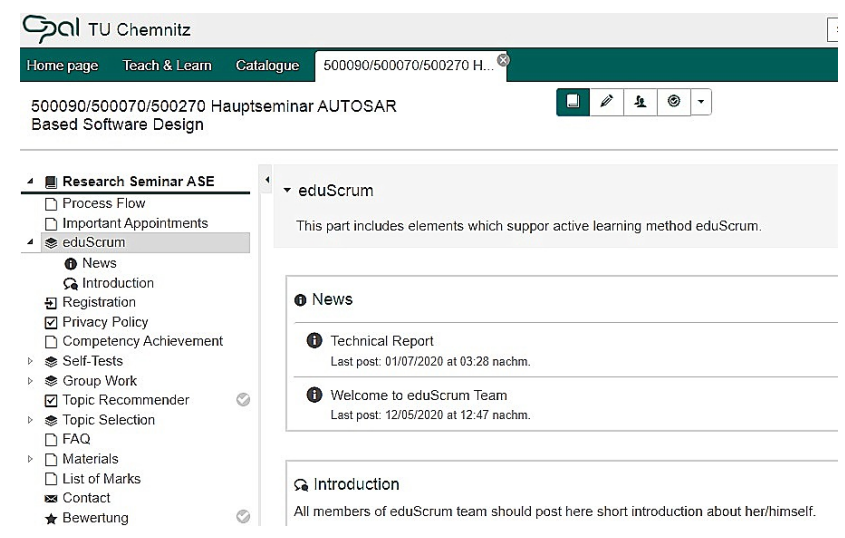

Figure 2: OPAL elements for eduScrum class

In Figure 2 the structure of the eduScrum elements within the OPAL course are depicted. The eduScrum class starts with an online phase. Hence, the Product Owner (course supervisor) invited the students to register within the eduScrum Team. The element eduScrum - Group 1 is the cover element for a single eduScrum group and consists of several sub elements. Within the sub element Sprints results of the defined sprints need to be uploaded when they are ready for discussion. The Presentation and Talk sub element collects presentation files and the preparations of the talks of the eduScrum Members. The Team building sub element is used for the eduScrum Team organization. Within this element students start to introduce themselves and register to the eduScrum Team. After building the eduScrum Team one of the members becomes the Scrum Master by an open discussion. Figure 3 shows a face to face meeting of eduScrum team students.

\subsection{Collaborative learning by Jigsaw}

Jigsaw is a cooperative learning method with group activity. Therefore the main topic is divided into parts and each student studies one part for a defined time. Afterwards groups are formed so that the learned information can be shred/taught (Soohyun et al. 2018; Jigsaw overview, 2021).

The Research Internship is offered at the Computer Engineering chair under the supervising of Prof. Dr. Wolfram Hardt every semester. The research internship is suitable for master students mainly from Automotive Software Engineering after the second semester. It is always offered at the summer semester (SS) and winter semester (WS). During the internship teaching is divided in presence phases and home studies. Students learn basic skills for scientific working and thinking. Major work packages include literature research, conceptual design, implementation, structured 

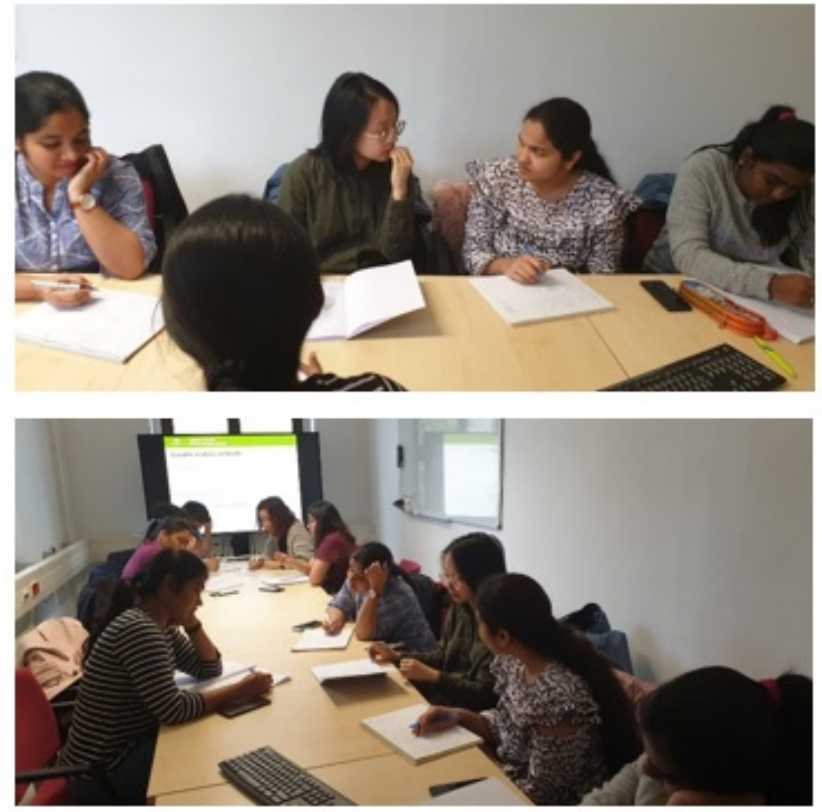

Figure 3: Students of eduScrum class

tests as well as critical analysis, discussion and technical documentation.

The phases of home studying are used for project-based active learning. It means that the students receive a relevant task to the current topic of the lecture with a broader range. They have to work on it at home and successfully produce a report in the form of slides and a presentation before the class followed by a discussion. For each semester a main topic like Image Processing for Advanced Driver Assistance Systems (ADAS) or Image Processing Filters in Automotive Data and Time-Triggered Framework (ADTF) is defined. These main topics can be split up into subtopics therefore it is suitable for the Jigsaw teaching approach. However the original Jigsaw approach was adapted to the needs of this subject. Normally a class consist of 5 to 15 students. In the WS 18/19 seven students attended the class.

Within the WS 18/19 the main topic Image Processing for Advanced Driver Assistance Systems (ADAS) was used. Parts of image processing for ADAS amongst others are lane detection, pedestrian detection, traffic light detection and traffic sign detection. Based on (Soohyun et al. 2018) the Jigsaw activity should not last too long. A maximum time of $30 \mathrm{~min}$ is suggested. So multiple jigsaw activities were included throughout the whole semester. Each student studied the relevant part of their topic at home. For example the literature research analysis for lane detection. Within the following lesson the students presented the part and a group discussion finalized the activity. At the end the teacher summarized all. So the learned input can be
Table 1: Jigsaw structure of the semester weeks

\begin{tabular}{|c|c|c|}
\hline Weeks & Subject & Comments \\
\hline $\mathrm{I}$ & Introduction & $\begin{array}{l}\text { Introduction of the subject } \\
\text { to the students with gen- } \\
\text { eral information like rules for } \\
\text { the lessons and homework } \\
\text { phases in combination with } \\
\text { technical topic introduction. }\end{array}$ \\
\hline II & Literature & $\begin{array}{l}\text { Research Traditional lecture } \\
\text { (slides modernized) }\end{array}$ \\
\hline III & $\begin{array}{l}\text { Jigsaw exercise } \\
1\end{array}$ & Literature Research \\
\hline IV & $\begin{array}{l}\text { Classroom ac- } \\
\text { tivity }\end{array}$ & $\begin{array}{l}\text { Presentation and discussion } \\
\text { of the results of the project- } \\
\text { based task }\end{array}$ \\
\hline \multicolumn{3}{|c|}{ Concept } \\
\hline $\mathrm{V}$ & $\begin{array}{l}\text { Jigsaw exercise } \\
2\end{array}$ & Concept Development \\
\hline VI & $\begin{array}{l}\text { Classroom ac- } \\
\text { tivity }\end{array}$ & $\begin{array}{l}\text { Presentation and discussion } \\
\text { of the results of the project- } \\
\text { based task }\end{array}$ \\
\hline \multicolumn{3}{|c|}{ Implementation } \\
\hline VII & $\begin{array}{l}\text { Classroom ac- } \\
\text { tivity }\end{array}$ & $\begin{array}{l}\text { Hands-on and short introduc- } \\
\text { tion of project-based task } 3\end{array}$ \\
\hline VIII & - & $\begin{array}{l}\text { no lesson, homework phase } \\
\text { for students }\end{array}$ \\
\hline IX & $\begin{array}{l}\text { Classroom ac- } \\
\text { tivity }\end{array}$ & $\begin{array}{l}\text { Presentation and discussion } \\
\text { of the results of the project- } \\
\text { based task }\end{array}$ \\
\hline \multicolumn{3}{|c|}{ Result and Evaluation } \\
\hline $\bar{X}$ & Lecture & $\begin{array}{l}\text { Traditional lecture (slides } \\
\text { modernized) }\end{array}$ \\
\hline $\mathrm{XI}$ & Jigsaw exercise & Result Summary \\
\hline XII & $\begin{array}{l}\text { Classroom ac- } \\
\text { tivity }\end{array}$ & $\begin{array}{l}\text { Presentation and discussion } \\
\text { of the results of the project- } \\
\text { based task }\end{array}$ \\
\hline
\end{tabular}

Documentation

used also for their own technical topic. Within the WS 18/19 the semester consist of 15 weeks teaching. The structure of the semester weeks with the adapted Jigsaw approach is presented in Table 1.

\subsection{Improvement of learning quality}

The hands-on and problem-solving teaching approach was used for the subject Automotive Software Engineering. For the support and usage of this new teaching approache 
a learning tool was developed (Englisch, Heller \& Hardt, 2018a; 2018b; English et al. 2019). The idea is the representation of automotive specific system architecture knowledge in a database. This knowledge contains information like software modules and their dependencies, functions and its parameters, functional models and so on. The main goal is to teach software developers from industry or research institutions and students at a university efficiently in details and specific features in the automotive domain by an eLearning System which contains graphical representation of this knowledge base.

In addition, a tool supporting the teacher in the preparation of tasks and questions was developed. That was necessary to provide a framework for generating tasks and questions for Quizzes or Self-tests for the students after the practical exercises during the hands-on and problemsolving teaching approaches. The presented concept is based on an automated generation of questions and tasks in the area of software engineering. This process is knowledge based, containing architectural knowledge like modules, functions, etc. Owning this knowledge is very important for software engineers beside the normal programming skills and abstract thinking. An efficient teaching approach in this area is the usage of animations. Workflows and sequences of computer systems are represented step by step by graphical effects within the animations. Essential data for the animations are traced and recorded before in a real and specific scenario defined by the teacher.

\subsection{Evaluation of active learning}

The DrIVE-MATH international project team together developed specific survey questions to measure success of implementation and students' acceptance of active learning methods in teaching (Pinto et al. 2019). The idea came from the Portugal team and questions were developed together based on their ongoing survey questions. The whole team worked collaboratively on one document and all contributed with teir own ideas to create correct questions for a common questionnaire.

Through joint work, five general core questions were agreed for the data acquisition at the partner universities involved. Moreover, 27 sub questions were formulated, which were assigned to the 5 main questions. For rating the questions a five point Likert scale was used with the following levels: 1 - strongly disagree, 2 - disagree, 3 - neutral, 4 - agree and 5 - strongly agree (see Appendix).

Chemnitz University of Technology team collected data online survey and for data processing applied the structure oriented evaluation model (Tudevdagva, 2014). The first group of questions focused on general acceptance of the method by students. The second group of questions tried ascertain how students are comparing active learning methods with traditional teaching. The third group of question targeted data collection on soft skills development of students. The fourth group of questions focused on impact knowledge of students by active learning method. The fifth group tried to gauge the opinion of students on the implementation of active learning methods in engineering universities teaching.

Because evaluation responses were only collected from volunteers a total of 15 valid answers were received and used for data processing (Tudevdagva, Heller \& Hardt, 2020).

\section{Summary}

\subsection{Statistical results}

The online questionnaire was developed and included directly in the OPAL course. The announcement for the assessment by an online questionnaire was distributed to the eduScrum test class students via the news function in the OPAL course. In total 40 students registered for the eduScrum class in the summer semester 2019 but only 15 of them responded to questionnaire.

The collected data were processed by the calculation rules of the structure oriented evaluation model (Tudevdagva, 2014, 2020). This model is a multidimensional and non-parametric evaluation model with a measure theoretical background. In using this model, it is assumed that we have $r=5$ key goal directions corresponding to our 5 question groups above. The sub questions describe sub goal directions of respective question group.

Let $s_{i}$ be for $i=1, \ldots, r$ the number of sub goals of $i$-th key goal or question group. Denote by

$A_{i j} \quad$ - the fact or event, that $j$-th sub goal of $i$ th key goal is reached, $i=1, \ldots, r, j=$ $1, \ldots, s_{i}$.

$B_{i} \quad$ - the event, that the $i$-th key goal is reached, $i=1, \ldots, r$,

$C$ - the event, that main goal of process is reached.

Thereby it is assumed that the events $A_{i j}, B_{i}$ and $C$ are logically linked so that

$$
C=\bigcap_{i=1}^{r} B_{i}=\bigcap_{i=1}^{r} \bigcup_{j=1}^{s_{i}} A_{i j}
$$




\begin{tabular}{|c|c|c|c|c|c|c|c|c|c|c|c|c|c|c|c|c|c|c|c|c|c|c|c|c|c|c|c|c|}
\hline & \multicolumn{4}{|c|}{$B_{1}$} & \multicolumn{10}{|c|}{$B_{2}$} & \multicolumn{8}{|c|}{$B_{3}$} & \multicolumn{2}{|c|}{$B_{4}$} & \multicolumn{3}{|c|}{$B_{5}$} & \multirow[b]{2}{*}{$Q_{e, k}^{*}(C)$} \\
\hline$k$ & $A_{11}$ & $A_{12}$ & $A_{13}$ & $A_{14}$ & $A_{21}$ & $A_{22}$ & $A_{23}$ & $A_{24}$ & $A_{25}$ & $A_{26}$ & $A_{27}$ & $A_{28}$ & $A_{29}$ & $A_{210}$ & $A_{31}$ & $A_{32}$ & $A_{33}$ & $A_{34}$ & $A_{35}$ & $A_{36}$ & $A_{37}$ & $A_{33}$ & $A_{41}$ & $A_{42}$ & $A_{51}$ & $A_{52}$ & $A_{53}$ & \\
\hline 1 & 5 & 5 & 5 & 5 & 5 & 5 & 5 & 5 & 5 & 5 & 5 & 5 & 5 & 5 & 5 & 5 & 5 & 5 & 5 & 5 & 5 & 5 & 5 & 5 & 5 & 5 & 5 & 1 \\
\hline 2 & 4 & 5 & 4 & 4 & 4 & 4 & 4 & 4 & 4 & 4 & 4 & 4 & 4 & 4 & 4 & 4 & 4 & 4 & 4 & 4 & 4 & 4 & 4 & 4 & 4 & 4 & 4 & 0.79 \\
\hline 3 & 4 & 4 & 3 & 3 & 3 & 3 & 3 & 3 & 3 & 3 & 3 & 3 & 3 & 3 & 2 & 2 & 2 & 2 & 2 & 2 & 2 & 2 & 3 & 3 & 3 & 3 & 2 & 0.44 \\
\hline 4 & 5 & 5 & 5 & 5 & 5 & 5 & 5 & 5 & 5 & 5 & 5 & 5 & 5 & 5 & 5 & 4 & 5 & 5 & 5 & 5 & 5 & 5 & 5 & 5 & 5 & 5 & 5 & 1 \\
\hline 5 & 4 & 4 & 3 & 4 & 3 & 3 & 3 & 4 & 3 & 3 & 3 & 3 & 4 & 3 & 2 & 2 & 3 & 2 & 2 & 3 & 3 & 3 & 4 & 4 & 3 & 3 & 3 & 0.57 \\
\hline 6 & 4 & 4 & 3 & 4 & 4 & 4 & 4 & 4 & 3 & 4 & 3 & 3 & 4 & 4 & 3 & 3 & 4 & 3 & 3 & 3 & 3 & 3 & 4 & 4 & 4 & 4 & 3 & 0.67 \\
\hline 7 & 5 & 5 & 5 & 5 & 5 & 5 & 5 & 5 & 5 & 5 & 5 & 5 & 5 & 5 & 5 & 5 & 5 & 5 & 5 & 5 & 5 & 5 & 5 & 5 & 5 & 5 & 5 & 1 \\
\hline 8 & 4 & 4 & 3 & 4 & 4 & 4 & 4 & 4 & 4 & 4 & 4 & 3 & 4 & 4 & 3 & 4 & 4 & 3 & 3 & 3 & 3 & 4 & 4 & 4 & 4 & 4 & 3 & 0.7 \\
\hline 9 & 5 & 5 & 5 & 5 & 5 & 5 & 5 & 5 & 5 & 5 & 5 & 5 & 5 & 5 & 5 & 5 & 5 & 5 & 5 & 5 & 5 & 5 & 5 & 5 & 5 & 5 & 5 & 1 \\
\hline 10 & 4 & 4 & 3 & 4 & 4 & 4 & 4 & 4 & 4 & 4 & 4 & 4 & 4 & 4 & 3 & 4 & 4 & 4 & 4 & 4 & 3 & 4 & 4 & 4 & 4 & 4 & 4 & 0.73 \\
\hline 11 & 5 & 5 & 5 & 5 & 5 & 5 & 5 & 5 & 4 & 4 & 5 & 5 & 5 & 5 & 4 & 4 & 4 & 4 & 4 & 5 & 4 & 5 & 4 & 5 & 5 & 4 & 5 & 1 \\
\hline 12 & 4 & 5 & 4 & 4 & 4 & 4 & 4 & 4 & 4 & 4 & 4 & 4 & 4 & 4 & 4 & 4 & 4 & 4 & 4 & 4 & 3 & 4 & 4 & 4 & 4 & 4 & 4 & 0.79 \\
\hline 13 & 5 & 5 & 4 & 4 & 4 & 4 & 4 & 4 & 4 & 4 & 4 & 5 & 4 & 4 & 4 & 4 & 4 & 4 & 4 & 4 & 4 & 4 & 4 & 4 & 4 & 4 & 4 & 0.84 \\
\hline 14 & 5 & 5 & 5 & 5 & 4 & 4 & 5 & 4 & 4 & 4 & 5 & 5 & 5 & 5 & 4 & 4 & 4 & 4 & 4 & 4 & 4 & 4 & 4 & 4 & 4 & 4 & 4 & 0.84 \\
\hline 15 & 5 & 5 & 5 & 5 & 5 & 5 & 5 & 5 & 4 & 5 & 5 & 5 & 5 & 5 & 5 & 4 & 5 & 4 & 4 & 5 & 5 & 5 & 4 & 5 & 5 & 4 & 5 & 1 \\
\hline$Q^{*}\left(A_{i j}\right)$ & 0.88 & 0.92 & 0.78 & 0.85 & 0.82 & 0.82 & 0.83 & 0.83 & 0.77 & 0.8 & 0.82 & 0.82 & 0.85 & 0.83 & 0.72 & 0.72 & \begin{tabular}{|l|c|}
0.78 \\
\end{tabular} & 0.72 & 0.72 & 0.77 & 0.72 & 0.78 & 0.8 & 0.83 & 0.82 & 0.78 & 0.77 & \\
\hline$Q_{e}^{*}\left(B_{i}\right)$ & & 0.5 & & & & & & & 0.8 & & & & & & & & & 0.76 & & & & & 0.8 & .83 & & 0.8 & & \\
\hline
\end{tabular}

Figure 4: SURE model evaluation results

holds. Then scores $Q$ and $Q_{e}$ can be assigned to this situation and the events $C, B_{i}$ and $A_{i j}$ such that

$$
Q(C)=\prod_{i=1}^{r}\left(1-\prod_{j=1}^{s_{i}}\left(1-Q\left(A_{i j}\right)\right)\right)
$$

and

$$
Q_{e}(C)=\sqrt[r]{\prod_{i=1}^{r}\left(1-\sqrt[s i]{\prod_{j=1}^{s_{i}}\left(1-Q\left(A_{i j}\right)\right)}\right)}
$$

holds. $Q_{e}(C)$ is the so-called calibrated score of $C$. Both scores have values in the interval $[0,1]$ and can be interpreted as characteristics which indicate how the process under consideration reaches its target. Values of $Q(C)$ or $Q_{e}(C)$ close to one indicate that the process goal is essentially achieved, while values close to zero indicate that it is essentially missed. In addition, the calibrated score describes a kind of average rating level. If all sub goals $A_{i j}$ are evaluated with $q^{\star}, 0 \leq q^{\star} \leq 1$, for instance, then also applies $Q_{e}^{\star}(C)=q^{\star}$.

In the following we will consider the calibrated score. To calculate a score $Q_{e}(C)$, the scores $Q\left(A_{i j}\right)$ are required, which of course are not known, as a rule. However, estimation values $q_{i j}^{\star(k)}$ for $Q\left(A_{i j}\right)$ can be obtained for each data record of questionaire by normalization of the rating values for $A_{i j}$. For this, let $x_{i j}^{(k)} \in\left[x^{\prime}, x^{\prime \prime}\right], x^{\prime}<x^{\prime \prime}$, be for $i=1, \ldots, r$, $j=1, \ldots, s_{i}$ and $k=1, \ldots, n$ the rating value for $A_{i j}$ in the $k$-th survey data record, that means the answer to the question $j$ of $i$-th question group of $k$-th survey data record in a sample with $n$ data records. Then we get normalized rating values $q_{i j}^{\star(k)}$ for $A_{i j}$ by

$$
q_{i j}^{\star(k)}=\frac{x_{i j}^{(k)}-x^{\prime}}{x^{\prime \prime}-x^{\prime}}, \quad k=1, \ldots, n .
$$

For our questionnaire it holds $x^{\prime}=1$ and $x^{\prime \prime}=5$. Then by averaging we obtain estimation values for the scores $Q_{e}\left(A_{i j}\right), Q_{e}\left(B_{i}\right)$ and $Q_{e}(C)$ as follows:

$$
\begin{gathered}
Q_{e}^{\star}\left(A_{i j}\right)=Q^{\star}\left(A_{i j}\right)=\frac{1}{n} \sum_{k=1}^{n} q_{i j}^{\star(k)}, \\
\left.Q_{e}^{\star}\left(B_{i}\right)=\frac{1}{n} \sum_{k=1}^{n}\left(1-\sqrt[s_{i}]{\prod_{j=1}^{s_{i}}\left(1-q_{i j}^{\star}(k)\right.}\right)\right)
\end{gathered}
$$

and

$$
Q_{e}^{\star}(C)=\frac{1}{n} \sum_{k=1}^{n} Q_{e, k}^{\star}(C)
$$

with

$$
Q_{e, k}^{\star}(C)=\sqrt[r]{\prod_{i=1}^{r}\left(1-\sqrt[s_{i}]{\prod_{j=1}^{s_{i}}\left(1-q_{i j}^{\star(k)}\right)}\right)} .
$$

The score $Q_{e}^{\star}(C)$ is denoted as an empirical calibrated score for $C$. This score is then a statistical version of a calibrated evaluation score $Q_{e}(C)$ and so is a statistical indicator of how the process has reached its goal in the sense of given survey data. For the further theoretical background of SURE model we refer to (Tudevdagva, 2014). The calculation of empirical scores can be carried out online with the Online Calculator of (Tudevdagva, 2021), for instance.

Figure 4 shows the obtained survey data as well as the corresponding empirical calibrated scores of survey for implementation of the AL method eduScrum.

As a result of this survey, an empirical evaluation score $Q_{e}^{*}(C)=0.82$ was obtained, which can be interpreted as a hint to an average satisfaction degree of students of $82 \%$ with eduScrum implementation. 
The five key questions or key goals $B_{1}, \ldots, B_{5}$ defined in Section 2.4 got empirical evaluation scores

$$
\begin{gathered}
Q_{e}^{\star}\left(B_{1}\right)=0.90, Q_{e}^{\star}\left(B_{2}\right)=0.85, Q_{e}^{\star}\left(B_{3}\right)=0.76, \\
Q_{e}^{\star}\left(B_{4}\right)=0.83 \text { und } Q_{e}^{\star}\left(B_{5}\right)=0.80,
\end{gathered}
$$

see last line in Figure 4.

All values are greater than zero. That means, none of the key goals failed, all key goals were reached. The obtained scores are comparatively high and indicate a quite high performance with respect to the achievement of key goals. The best evaluation score is the 0.90 score which refers to key question $B_{1}$ - the learning experience of students with active learning methods. The lowest evaluation score is 0.76 which reflects how students compare active learning methods with traditional teaching.

Figure 4 shows empirical evaluation scores $Q\left(A_{i j}\right)$ of all sub goals and sub questions. respectively, see second line from below in Figure 4. The highest evaluation score of 0.92 was obtained for the question "The use of innovative active learning methods should be an integral part of engineering education" - $A_{12}$. That value indicates that the eduScrum active learning method in teaching motivates students in learning.

Five different sub goals of $B_{3}$ received comparatively low evaluation scores from students.

- "The following soft skill was developed by active learning: Leadership" - $A_{31}$

- "The following soft skills were developed by active learning: Personal and social responsibility" - $A_{32}$

- "The following soft skill was developed by active learning: Interest in teamwork" - $A_{34}$

- "The following soft skills were developed by active learning: Negotiation and conflict resolution" - $A_{35}$

- "The following soft skill was developed by active learning: Emphatic behavior" - $A_{37}$

These are hints that soft skills which should be developed by the active learning method eduScrum are not being reached as expected before implementation. As a consequence, the third key goal received a relatively smaller empirical evaluation score than the other key goals.

\subsection{Pros/cons}

Each teaching method has its advantages and disadvantages. Of course, this also applies to active learning methods. The study showed pros of active learning methods of considered courses as follows:

- Students accepted eduScrum as a motivating technique in teaching;
- The students felt safer with the support of the product owner;

- The task list was useful for the students to orientate themselves in the ongoing learning process and to maintain the learning progress;

- Sprint helps students to see some results in between;

- Peer review in the eduScrum team was helpful to improve presentations and the technical report;

- The grades of the students in the eduScrum group were best in the course;

- Jigsaw method was very useful for helping students to understand their tasks;

- Hands on helped students at solving the given task during self study.

Cons of active learning methods in selected courses were:

- Students usually had no experience in eduScrum previously and there were implementation issues;

- Sometimes students didn't like weekly request from Product owner;

- The eduScrum method did not really support the development of soft skills;

- Not all students enjoy teamwork, in this case Jigsaw wasn't the best method for them;

- Student materials sometimes need to be separated by subject due to the level of knowledge of the students.

The implementation of active learning methods in teaching influenced the students' view to collaboration in class and with lecturers. The usual way in German higher education classes is to be good listener and usually work alone. All methods for active learning supported students' collaboration and team work. Finally, students who were involved into our test groups liked the methods.

The main aim of this project was to support students of technical universities to keep their motivation for study. This is not an easy goal. Success with studying and motivation of students depend on many different factors.

But educators develop many different teaching and learning methods. Active learning methods are one of trying to fill this request for better teaching in universities.

We implemented some active learning methods, namely: eduScrum, Jigsaw, PBL and hands on for selected courses. What we have learned from our case-study?

1. Selection of courses for implementation of active learning methods.

In our case study we did not have many choices. Not all professors like to test new methods in their courses. Therefore we selected some courses from one professorship: Computer engineering. If we 
Table 2: Sub goals and evaluation scores

\begin{tabular}{|c|c|c|}
\hline Sub goals of evaluation & & Score \\
\hline Active learning is an useful learning strategy & $A_{11}$ & 0.88 \\
\hline $\begin{array}{l}\text { The use of innovative active learning methods should } \\
\text { be an integral part of engineering education }\end{array}$ & $A_{12}$ & 0.92 \\
\hline I can apply learned skills to other scenarios & $A_{13}$ & 0.78 \\
\hline $\begin{array}{l}\text { would recommend my colleagues to use it for study } \\
\text { purposes }\end{array}$ & $A_{14}$ & 0.85 \\
\hline $\begin{array}{l}\text { Compared to traditional teaching approach the active } \\
\text { learning method increases my interest in learning }\end{array}$ & $A_{21}$ & 0.82 \\
\hline $\begin{array}{l}\text { Compared to traditional teaching approach the active } \\
\text { learning methods increases my motivation in study- } \\
\text { ing }\end{array}$ & $A_{22}$ & 0.82 \\
\hline $\begin{array}{l}\text { Compared to traditional teaching approach the active } \\
\text { learning method motivates me to study more effec- } \\
\text { tively }\end{array}$ & $A_{23}$ & 0.83 \\
\hline $\begin{array}{l}\text { Compared to traditional teaching approach the active- } \\
\text { learning methods encourage me to study more deeply }\end{array}$ & $A_{24}$ & 0.83 \\
\hline $\begin{array}{l}\text { Compared to traditional teaching approach the active- } \\
\text { learning methods are more demanding of my prepara- } \\
\text { tion }\end{array}$ & $A_{25}$ & 0.77 \\
\hline $\begin{array}{l}\text { Compared to traditional teaching approach the active- } \\
\text { learning methods are more beneficial for gaining } \\
\text { knowledge }\end{array}$ & $A_{26}$ & 0.80 \\
\hline $\begin{array}{l}\text { Compared to traditional teaching approach the active- } \\
\text { learning methods enlarges my professional insight }\end{array}$ & $A_{27}$ & 0.82 \\
\hline $\begin{array}{l}\text { Compared to traditional teaching approach the active- } \\
\text { learning methods are more creative }\end{array}$ & $A_{28}$ & 0.82 \\
\hline $\begin{array}{l}\text { Compared to traditional teaching approach the active- } \\
\text { learning methods are more convenient and pleasant }\end{array}$ & $A_{29}$ & 0.85 \\
\hline $\begin{array}{l}\text { Compared to traditional teaching approach the active- } \\
\text { learning methods are more accessible and comfort- } \\
\text { able }\end{array}$ & $A_{210}$ & 0.83 \\
\hline
\end{tabular}

The following soft skill of me was developed by active $\begin{array}{lll}A_{31} & 0.72\end{array}$ learning: Leadership

\begin{tabular}{lll}
\hline The following soft skills of me were developed by ac- & $A_{32}$ & 0.72
\end{tabular} tive learning: Personal and social responsibility

\begin{tabular}{llll}
\hline The following soft skills of me were developed by ac- & $A_{33}$ & 0.78
\end{tabular} tive learning: Flexibility/adaptability

\begin{tabular}{llll}
\hline The following soft skill of me was developed by active & $A_{34}$ & 0.72
\end{tabular} learning: Interest in teamwork

\begin{tabular}{llll}
\hline The following soft skills of me were developed by ac- & $A_{35}$ & 0.72
\end{tabular} tive learning: Negotiation and conflict resolution

\begin{tabular}{lll}
\hline The following soft skills of me were developed by ac- & $A_{36}$ & 0.77
\end{tabular} tive learning: Professionalism/ethics

\begin{tabular}{lll}
\hline The following soft skill of me was developed by active & $A_{37}$ & 0.72
\end{tabular} learning: Empathetic behavior

\begin{tabular}{llll}
\hline The following soft skill of me was developed by active & $A_{38}$ & 0.78
\end{tabular} learning: Creativity

The knowledge acquired by active-learning methods $A_{41} \quad 0.80$ integrates theory and practice

\begin{tabular}{llll}
\hline The knowledge acquired by active-learning methods & $A_{42}$ & 0.83
\end{tabular} being more applicable in my professional orientation

EduScrum communication elements in OPAL LMS $A_{51} 0.82$ were useful

EduScrum forums in OPAL supported virtual collabo- $A_{52} \quad 0.78$ ration with other students

$\begin{array}{lll}\text { The online version of active learning EduScrum en- } & A_{53} & 0.77\end{array}$ hances face to face teaching could select some other courses from bachelor level it could lead to different results;

2. Implementation of active learning methods into teaching of master level was welcomed by students. The grades of eduScrum students were much better than from students of traditional groups. Lecturers who worked with normal groups were impressed by the very positive reactions of students to active learning environments. This supports possible future implementations of active learning methods in other courses;

3. Changes in courses' curricula are not easy in German universities.

The DrIVE-MATH project is very useful to show stakeholders and other professors the positive outcomes from the implementation of active learning methods in students' success and motivation to study (Tudevdagva, Heller \& Hardt, 2019).

4. Problems with cultural differences during active learning.

The active learning methods are more studentcentered. That means students have a more active role in their learning process, participate more at lectures and create teams for practical tasks. All selected courses were taught in English and more than 90\% of our students were international students from Russia, India, China, UK, Korea, Bangladesh, Turkey, Syria, Congo, Czech, Poland and Latvia. Their learning attitudes and their backgrounds were very different. That sometimes led to small communication problems and negotiation skills in teamwork.

Throughout the project, we published several research papers at international and national conferences and in journals (Tudevdagva et al. 2018; Hardt \& Tudevdagva, 2018).

Acknowledgement: The authors have been partially supported by DrIVE-MATH (2017-1-PT01-KA203-035866) which is funded by the Erasmus+ Program of the European Union.

Author contributions: The active learning method eduScrum was implemented into classroom teaching by Uranchimeg Tudevdagva and Jigsaw and hands-on methods were implemented by Ariane Heller into teaching. Wolfram Hardt analysed the data. Uranchimeg Tudevdagva wrote the paper, all authors have approved the final version.

Conflict of interest: The authors state no conflict of interest. 


\section{References}

Englisch, N., Heller, A. \& Hardt, W. (2018a). “Learning System for Automotive Specific System Architecture Based on s Knowledge Base", in Proceedings of the 12th International Technology, Education and Development Conference (INTED), pp. 8996 - 9002, IATED International Association of Technology, Education and Development, Spain, March 2018. ISBN: 978-84-697-9480-7, doi: 10.21125/inted.2018.2190

Englisch, N., Heller, A. \& Hardt, W. (2018b). “Automated Generation of Tests For Education in Software Engineering”, in Proceedings of the 10th annual International Conference on Education and New Learning Technologies (EDULEARN), IATED International Association of Technology, Education and Development, Spain, July 2018. p.8478-8484, ISBN: 978-84-09-02709-5, doi: 10.21125/edulearn.2018.1976

Englisch, N., Hardt, W., Heller, A., Tudevdagva, U., Tonndort-Martini, J. \& Gaitzsch, L. (2019). 'Adaptive Learning System in Automotive Software Engineering', In 27th International Conference on Software, Telecommunications and Computer Networks (SoftCOM), IEEE Computer Society, September 2019. ISBN: 978-1-7281-3711-7

EduScrum Team (2020). The eduScrum Guide, Jan. 2020, Retrieved from https://eduscrum.com.ru/wpcontent/uploads/2020/01/The_eduScrum-guide-

English_2.0_update_21-12-2019.pdf

Hardt, W. \& Tudevdagva, U. (2018). "Artificial intelligence (AI) makes learner-centred learning successful”, p. 164, Open Access Government. - pagesuite, July 2018. ISSN: 2055-7612.

Lectera (2018). Self development, Retrieved from https://magazine.lectera.com/articles/willy-wijnands-founderof-dutch-eduscrum-project-on-the-future-of-education

Nicola, S., Pinto, C.M.A. \& Mendonça, J. (2018). The role of education on the acquisition of 21st century soft skills by Engineering students, Changing Higher Education One Teacher at a Time, UA Editora, ISBN 978-972-789-548-9.

Overview, (2021). The Jigsaw Classroom. Retrieved from https://www.jigsaw.org/

Pinto, C., Nicola, S. , Mendonça, J. \& Velichová, D. (2019). Best teaching practices in the first year of the pilot implementation of the project DrIVE-MATH, Teaching Mathematics and Its Applications: International Journal of the IMA. Teaching Mathematics and Its Applications (2019), pp. 1-13. doi:10.1093/teamat/hrz004.

Soohyun Nam Liao et al., (2018). Classroom Experience Report on Jigsaw Learning, ITiCSE '18, July 2-4 2018 Larnaca, Cyprus ACM, ISBN: 978-1-4503-5707-4, https://doi.org/10.1145/3197091.3197118

Tudevdagva, U., Heller, A. \& Hardt, W. (2020). An Implementation and Evaluation Report of the Active Learning Method EduScrum in Flipped Class, in journal International Journal of Information and Education Technology (IJIET), Vol.10(9): pp. 649-654 ISSN: 2010-3689, doi: 10.18178/ijiet.2020.10.9.1438

Tudevdagva, U. (2014). Structure Oriented Evaluation Model for ELearning. Wissenschaftliche Schriftenreihe Eingebettete Selbstorganisierende Systeme, Universitätsverlag Chemnitz, Chemnitz, Germany, July 2014. 123 p., ISBN: 978-3-944640-20-4, ISSN: 2196-3932.

Tudevdagva, U. (2020). Structure-Oriented Evaluation, Springer Nature Switzerland AG, ISBN: 978-3-030-44806-6, DOI:10.1007/978-3030-44806-6.
Tudevdagva, U. (2020). SURE model evaluation, http://www.uranchimeg.com/sure/eva.php (01.05.2021).

Tudevdagva, U., Heller, A. \& Hardt, W. (2019). 'Short Review of Online Math Courses on MOOCs ', in Proceedings of the International Symposium on Computer Science, Computer Engineering, and Education Technologies (ISCSET), 17-19 July 2019, pp. 52-56, ISBN: 978-3-95908-174-0.

Tudevdagva, U., Auyush, Y., Daniela, V. \& Tsetsegsuren, T. (2018). The structure of universities: Comparison analyse of some universities from Mongolia, Russia, Germany and Slovakia, in Higher Education journal, pp. 86 - 96, 2018.

Wijnands, W. (2021). The eduScrum Team, Retrieved from https://www.eduscrum.nl/about/ 


\section{Appendix}

Question 1. General acceptance of active learning methods

\begin{tabular}{|l|l|l|l|l|l|l|}
\hline S/N & Criteria & $\begin{array}{l}\text { Strongly } \\
\text { Disagree }\end{array}$ & Disagree & Neutral & Agree & $\begin{array}{l}\text { Strongly } \\
\text { Agree }\end{array}$ \\
\hline 1. & $\begin{array}{l}\text { The active learning is an useful learning } \\
\text { strategy }\end{array}$ & & & & \\
\hline 2. & $\begin{array}{l}\text { The use of innovative active-learning } \\
\text { methods should be an integral part of } \\
\text { engineering education }\end{array}$ & & & & \\
\hline 3. & $\begin{array}{l}\text { I can apply learned skills into other } \\
\text { scenarios }\end{array}$ & & & & & \\
\hline 4. & $\begin{array}{l}\text { I would recommend my colleagues to use } \\
\text { it for study purposes. }\end{array}$ & & & & & \\
\hline
\end{tabular}

Figure 5: Question 1

Question 2. Compared to traditional teaching approach the active-learning methods:

\begin{tabular}{|c|c|c|c|c|c|c|}
\hline $\mathrm{S} / \mathbf{N}$ & Criteria & $\begin{array}{l}\text { Strongly } \\
\text { Disagree }\end{array}$ & Disagree & Neutral & Agree & $\begin{array}{l}\text { Strongly } \\
\text { Agree }\end{array}$ \\
\hline 1. & $\ldots$ increases my interest in learning & & & & & \\
\hline 2. & ... increases my motivation in studying & & & & & \\
\hline 3. & ...motivates me to study more effectively & & & & & \\
\hline 4. & ...encourage me to study more deeply & & & & & \\
\hline 5. & $\ldots$ are more demanding my preparation & & & & & \\
\hline 6. & $\begin{array}{l}\text { are more beneficial for gaining } \\
\text { knowledge }\end{array}$ & & & & & \\
\hline 7. & ... enlarges my professional insight & & & & & \\
\hline 8. & $\ldots$ are more creative & & & & & \\
\hline 9. & $\ldots$ are more convenient and pleasant & & & & & \\
\hline 10. & ... are more accessible and comfortable & & & & & \\
\hline
\end{tabular}

Figure 6: Question 2

Question 3: The following soft skills of me was developed by active learning:

\begin{tabular}{|l|l|l|l|l|l|l|}
\hline S/N & Criteria & $\begin{array}{l}\text { Strongly } \\
\text { Disagree }\end{array}$ & Disagree & Neutral & Agree & $\begin{array}{l}\text { Strongly } \\
\text { Agree }\end{array}$ \\
\hline 1. & Leadership & & & & & \\
\hline 2. & Personal and social responsibility & & & & & \\
\hline 3. & Flexibility/adaptability & & & & & \\
\hline 4. & Interest in teamwork & & & & & \\
\hline 5. & Negotiation and conflict resolution & & & & & \\
\hline 6. & Professionalism/ethics & & & & & \\
\hline 7. & Empathic behavior & & & & & \\
\hline 8. & Creativity & & & & & \\
\hline
\end{tabular}

Figure 7: Question 3

Question 4: The knowledge acquired by active-learning methods:

\begin{tabular}{|l|l|l|l|l|l|l|}
\hline S/N & Criteria & $\begin{array}{l}\text { Strongly } \\
\text { Disagree }\end{array}$ & Disagree & Neutral & Agree & $\begin{array}{l}\text { Strongly } \\
\text { Agree }\end{array}$ \\
\hline 1. & integrates theory and practice & & & & & \\
\hline 2. & $\begin{array}{l}\text { being more applicable in my professional } \\
\text { orientation }\end{array}$ & & & & & \\
\hline
\end{tabular}

Figure 8: Question 4

Question 5: eduScrum in the LMS OPAL

\begin{tabular}{|l|l|l|l|l|l|l|}
\hline S/N & Criteria & $\begin{array}{l}\text { Strongly } \\
\text { Disagree }\end{array}$ & Disagree & Neutral & Agree & $\begin{array}{l}\text { Strongly } \\
\text { Agree }\end{array}$ \\
\hline 1. & $\begin{array}{l}\text { eduScrum communication elements in } \\
\text { OPAL LMS were useful }\end{array}$ & & & & \\
\hline 2. & $\begin{array}{l}\text { eduScrum forums in OPAL supported } \\
\text { virtual collaboration with other students }\end{array}$ & & & & & \\
\hline 3. & $\begin{array}{l}\text { The online version of active learning } \\
\text { eduScrum enhances face to face teaching }\end{array}$ & & & & \\
\hline
\end{tabular}

Figure 9: Question 5 